Informatika i sistemy upravleniya. - 2017. - No. 1(51). - P. 85-94.

Bobarykin N.D. (bobarykin.48@mail.ru), Tristanov A.B., Grafova E.N.

Kaliningrad state technical university

\title{
AUTOMATED CONTROLOF THE GROUND WATER LINE THAT ENABLES RISK REDUC- TION OF PEAT SWAMPS INFLAMMATION AND FOREST UNDERFLOODING
}

This article reflects the results of numerical calculations of risk attenuation of peat swamps inflammation and woodlandflooding. These calculations are based on mathematical modelling and strategy to control the groundwater level (GWL) in polder systems (PS).

Keywords: differential equations, mathematical models of PS, system of automatic control, groundwater level, industrial controller, indicators of quality, misalignment, partial differential equations.

DOI: 10.22250/isu.2017.51.85-94

\section{For citation:}

Bobarykin N.D., Tristanov A.B., Grafova E.N. AUTOMATED CONTROLOF THE GROUND WATER LINE THAT ENABLES RISK REDUCTION OF PEAT SWAMPS INFLAMMATION AND FOREST UNDERFLOODING // Informatika i sistemy upravleniya. - 2017. - No. 1(51). P.85-94. 